African Crop Science Journal by African Crop Science Society is licensed under a Creative Commons Attribution 3.0 Uganda License. Based on a work at www.ajol.info/ and www.bioline.org.br/cs DOI: https://dx.doi.org/10.4314/acsj.v29i3.3

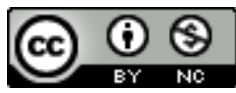

\title{
EFFECTS OF GAMMA IRRADIATION AND ETHYL METHANE SULPHONATE ON MORPHOMETRIC TRAITS AND PREVALENCE OF COMMON VIRAL DISEASES AND WHITEFLIES IN CASSAVA
}

\author{
J.K. BAGUMA ${ }^{1,3}$, E. OGWOK ${ }^{1,4}$, W. ELEGBA ${ }^{2}$, A. SARKODIE ${ }^{2}$, S. OTU ${ }^{2}$, H.B. APIO ${ }^{1}$, \\ R.S. KAWUKI ${ }^{1}$, A. BUA ${ }^{1}$, K. DANSO ${ }^{2}$ and T. ALICAI ${ }^{1}$ \\ ${ }^{1}$ National Crops Resources Research Institute, Namulonge, P. O. Box 7084, Kampala, Uganda \\ ${ }^{2}$ Biotechnology and Nuclear Agriculture Research Institute, Ghana Atomic Energy Commission, \\ P. O. Box LG80, Accra, Ghana \\ ${ }^{3}$ School of Agricultural Sciences, Makerere University, P. O. Box 7062, Kampala, Uganda \\ ${ }^{4}$ Biology Department, Faculty of Science, Muni University, P. O. Box 725, Arua, Uganda \\ Corresponding authors: bagumakj@gmail.com,emmyogwok@gmail.com
}

(Received 13 November 2020; accepted 23 August 2021)

\begin{abstract}
Cassava (Manihot esculenta Crantz) is an important staple and food security crop for millions of people in Africa. However, its nutritional value is limited; yet its productivity is constrained by several pests and diseases. Induced mutagenesis is one approach with the potential to overcome such biotic stresses. The objective of this study was to assess the variability in morphometric traits and prevalence of common viral diseases and whiteflies in cassava to different doses and concentrations of gamma irradiation and ethyl methane sulphonate (EMS) treatments. The effects were assessed on seed germination and growth of stakes, as well as foliar viral disease symptoms and whitefly counts. Radiosensitivity tests revealed $\mathrm{LD}_{50}$ for sprouting as 37.6Gy for $\gamma$-irradiation and $0.08 \%$ for EMS treatment. There was notable decrease in sprout, epicotyl length, shoot height, petiole length and number of leaf lobes, with increasing $\gamma$-ray doses and EMS concentrations. Contrastingly, total chlorophyll content increased with increasing doses of $\gamma$-rays and EMS concentrations. Basing on foliar whitefly counts and disease symptoms, there was a general increase in susceptibility to whitefly infestation and cassava mosaic disease (CMD) incidence. Significantly varying levels of resistance or tolerance to whiteflies and CMD were observed among plantlets derived from irradiated and EMS treated stems, compared to the controls. These findings lay a foundation for more future research on breeding for various traits, including disease resistance in cassava using induced mutagenesis approach.
\end{abstract}

Key Words: Mutagenesis, radio-sensitivity, whitefly 
Le manioc (Manihot esculenta Crantz) est une culture de base et de la sécurité alimentaire importante pour des millions de personnes en Afrique. Cependant, sa valeur nutritionnelle est limitée; pourtant, sa productivité est limitée par plusieurs ravageurs et maladies. La mutagenèse induite est une approche ayant le potentiel de surmonter de tels stress biotiques. L'objectif de cette étude était d'évaluer la variabilité des traits morphométriques et la prévalence des maladies virales courantes et des aleurodes du manioc en raison de l'exposition à différentes doses et concentrations des traitements par $1^{\text {‘ }}$ irradiation gamma et éthyl méthane sulfonate (EMS). Les effets ont été évalués sur la germination des graines et la croissance des tuteurs, ainsi que sur les symptômes de la maladie virale foliaire et le nombre des aleurodes. Les tests de radiosensibilité ont révélé que la DL50 pour la germination était de 37,6 Gy pour l'irradiation et de $0,08 \%$ pour le traitement EMS. Il y avait une diminution notable de la pousse, de la longueur de l'épicotyle, de la hauteur des pousses, de la longueur du pétiole et du nombre des lobes foliaires, avec l'augmentation des doses de rayons et des concentrations EMS. En revanche, la teneur totale en chlorophylle augmentait avec l'augmentation des doses de rayons et des concentrations EMS. Sur la base des dénombrements foliaires des aleurodes et des symptômes de la maladie, il y avait une susceptibilité généralement accrue à l'infestation des aleurodes et à l'incidence de la maladie de la mosaïque du manioc (CMD). Des niveaux significativement variables de résistance ou de tolérance aux aleurodes et à la CMD ont été observés parmi les plantules dérivées de tiges irradiées et traitées par EMS, par rapport aux témoins. Ces résultats jettent les bases des autres recherches futures sur la sélection pour les divers caractères, y compris la résistance aux maladies du manioc en utilisant une approche de mutagenèse induite.

Mots Clés : Mutagenèse, radiosensibilité, aleurode

\section{INTRODUCTION}

Cassava (Manihot esculenta Crantz) provides a rich source of carbohydrates for nearly one million people in sub-Saharan Africa (Nassar and Ortiz, 2010), majority of whom are poor. However, it is reported to have a very limited nutritional value (Nassar and Ortiz, 2010; FAO, 2010); yet, its breeding and productivity are constrained by long propagation cycles (Jennings and Iglesias, 2002; Kawuki et al., 2011); which facilitate infection and transmission of systemic viral diseases (Ogwok et al., 2015).

Over the years, cassava improvement programmes have focused on use of conventional methods to breed for varieties with useful traits (Jennings and Iglesias, 2002). Conventional breeding, however, is laborious and time consuming, as it involves a long procedure from parental choice to cultivar release (Shimelis and Laing, 2012). Recently, efforts have been made to transfer genes from related or other species into the crop via genetic engineering or transformation (Tayloret al., 2004; Ogwok et al., 2015). Although this technique is specific and time saving, there is public outcry against the technology, besides the regulatory constraints in several countries in Africa (Adenele et al., 2012), including Uganda.

Although there are few publications on mutation breeding in cassava, particularly in sub-Saharan Africa, induced mutagenesis offers a huge potential to overcome breeding challenges that face the crop. Since the discovery of radiations, including gamma ray radiation, over 3,000 mutant crop varieties comprising cereals (1541), ornamentals (709), legumes (432), oil seeds (145) and others (312), have been produced through induced mutagenesis (FAO and IAEA, 2011). Of these varieties, only two cassava mutants have been reported. These include varieties "Tebankye" 
and "Fuxuan 01" in Ghana and China, respectively (Maluszynski et al., 2000; Yan et al., 2013). The former exhibited improved attributes of large sized starch granules in the tubers, cooking quality and tolerance to African cassava mosaic virus disease (ACMVD). Also, there have been reports on successful generation of putative cassava mutant lines, with higher yields and starch content, from gamma-irradiated stakes (Khumaida et al., 2015 and 2017) and distinct variations in root phenotypes in a mutant population derived from irradiated botanical seeds at International Centre for Tropical Agriculture (CIAT), Cali, Colombia. In most of these studies, physical mutagens, especially gamma irradiation, have been used for mutation induction.

In Uganda, we have set up an improvement programme for cassava to develop mutants which are high yielding, with resistance to the common viral diseases, cassava brown streak disease (CBSD) and cassava mosaic disease (CMD); as well as whitefly infestation in farmer preferred varieties. Both diseases are devastating, causing severe yield losses (FAO, 2011), with CBSD being the most damaging (Legg et al., 2011) as it causes root rot and almost $100 \%$ yield loss due to the necrosis it causes to the starch storage tissues (Hillocks and Thresh, 1998). Both CBSD and CMD are transmitted by the whitefly (Bemisia tabaci) (Maruthi et al., 2005), which is a common cassava pest, but also by mechanical means (Lister, 1959) and through the exchange of infected cassava cuttings among farmers.

Induced mutations are of considerable value in creating variability in agronomically important traits that can be exploited in plant breeding programmes (Liu et al., 2004). Therefore, the objective of this study was to assess the variability in morphometric traits and prevalence of common viral diseases and whiteflies in cassava to different doses and concentrations of gamma irradiation and ethyl methane sulphonate (EMS) treatments.

\section{MATERIALS AND METHODS}

Experimental site and plant materials. The experiment was carried out once in the screen house and tissue culture laboratory of the Biotechnology and Nuclear Agriculture Research Institute (BNARI) of the Ghana Atomic Energy Commission (GAEC). Three cassava accessions were selected for this study, two from BNARI farm and one from National Crops Resources Research Institute (NaCRRI), Namulonge in Uganda. The BNARI accessions (Bankye Borodie and BNARI-UK) were stakes; while the NaCRRI accession (NASE 14) were seeds (because stakes could not be carried to Ghana due to phytosanitary restrictions). These accessions were chosen because they are among the farmer-preferred varieties for good yields in Ghana and Uganda. However, the BNARI accessions succumb to cassava mosaic disease (CMD); while the NaCRRI accession is resistant to CMD and only tolerant to CBSD. For the BNARI accessions, we deliberately used materials with visible CMD symptoms so as to be able to evaluate the effect of the mutagenic treatment on the disease prevalence using foliar symptoms. A total of 135 lignified stakes, with about 3-5 nodes each were prepared from each accession; while 240 dry seeds of NASE 14 were prepared for mutagenic treatment.

Gamma irradiation. To determine the sensitivity of the selected varieties to gamma rays, 15 stakes of each accession were irradiated at $0,15,20,30$ or $45 G y$ using ${ }^{60} \mathrm{Co}$ gamma source, at the Radiation Technology Centre (RTC) of GAEC prior to planting. The irradiated stakes were immediately planted in poly bags filled with garden soil, and placed in a plant barn.

The experiment was set up in a split plot design with two factors (Bankye Borodie and BNARI-UK varieties and mutagens) and three replicates. The main factor was the gamma dose and the sub-plot was the variety. Five 
pots were set up per sub-plot and one stake planted vertically in each pot. The stakes were periodically watered throughout the entire period of the experiment.

The effect of gamma irradiation on NASE 14 seeds was determined by irradiating 45 seeds of NASE 14 at $0,100,200,300$ or $400 G y$. The irradiated seeds were immediately planted in poly bags, filled with garden soil in a screen house at BNARI $\left(43 \pm 1^{\circ} \mathrm{C}\right.$, under natural light). The pots were initially kept covered with black polyethylene sheet, to create dark conditions for augmented seed germination. The experiment was set up in a completely randomised design, in three replicates, with seeds of same gamma dose in the same plot. Four pots were planted per plot and three seeds were planted in each pot.

\section{Ethylmethane sulphonate (EMS)} treatment. The effect of EMS on morphometric features and disease prevalence in cassava plantlets derived from cassava seeds and stakes were evaluated by immersing the seeds and stakes in $0.05,0.1$, and $0.15 \%$ (v/ v) EMS solutions, including the controls. Fresh solutions of EMS (Sigma-Aldrich, USA) were prepared in $20 \%$ dimethyl sulfoxide (DMSO). In each solution, 15 cuttings of each variety were immersed and kept at room temperature under a fume chamber. After 24 hours, the EMS solutions were decanted, stakes rinsed in tap water and immediately planted in polybags filled with garden soil. The experiment was set up in a split-plot design as previously described. The main plot was the EMS concentration and the sub-plot was the variety. Five pots were set up per concentration in three replicates. One stake was planted vertically in each pot. The stakes were periodically watered using a watering can.

Similarly, the effect of chemical mutagenesis on the seeds was evaluated by soaking the seeds in distilled water for 24 hours; followed by treating them in EMS solutions as above. The treated seeds were immediately planted in poly bags filled with garden soil in the screen house as above. Four pots were set up per concentration. And two seeds were planted in each pot. The experiment was set up in a completely randomised design in three replicates.

Meristem culture initiation of the putative mutants. Apical shoot tips were obtained from the sprouts of gamma irradiated and EMS treated cassava stakes, washed with soapy water and then rinsed under running tap water for 30 minutes. The shoot tips were then surface-sterilised by immersing in 10\% chlorox solution for five minutes, then in $70 \%$ ethanol for three minutes. In each case, the shoot tips were vigorously agitated under the laminar flow hood, and thereafter rinsed twice with sterile distilled water.

Apical meristems were excised from the sterilised shoot tips under a stereomicroscope (Leica 2000, China), using a sterile scalpel and pair of forceps, and inoculated onto $15 \mathrm{ml}$ shoot initiation medium containing Murashige and Skoog medium (MS) (Duchefa biochemie, Nertherlands), supplemented with $30 \mathrm{gL}^{-1}$ sucrose, and $3.5 \mathrm{gL}^{-1}$ phytagel as gelling agent. The $\mathrm{pH}$ of media had been adjusted to 5.8 before autoclaving at $121^{\circ} \mathrm{C}$ for 15 minutes. The cultures were incubated at $26 \pm 1^{\circ} \mathrm{C}$ under a 16/8 hr (day/night) photoperiod.

CMD incidence and severity in the putative mutants. Foliar CMD incidence and symptom severity were scored at 14 and 36 days after planting (DAP). CMD incidence was scored basing on the presence (score 1) or absence (score 0 ) of foliar symptoms, whereas disease severity was scored based on a 5-point scale as previously described by Njock (1994); where a score of 1 means asymptomatic condition and a score 5 imply over $50 \%$ of the leaf show foliar symptoms.

Data collection and analysis. Different kinds of datasets on morphometric characters and foliar disease symptoms were generated in the barn, screen house and laboratories. Most of 
these were collected using a "Field Book App" (Rife and Poland, 2014). These included sprout or germination counts, foliar CMD incidence and severity, whitefly count, epicotyl length, shoot height, petiole length, number of leaf lobes, chlorophyll content and meristem initiation response of mutants, as well as still pictures at different stages. Height and length were measured using a meter rule, whereas chlorophyll content was determined using a CCM-200 plus Chlorophyll content meter (Optisciences, USA).

The datasets were processed using Excel computer software package; and thereafter, subjected to analysis of variance (ANOVA) using GenStat statistical software, edition 12. The Least Significant Differences (LSD) was used to compare means at the 5\% significance level.

\section{RESULTS AND DISCUSSION}

Lethal dose for gamma irradiation and EMS treatment. For gamma irradiation and EMS treatment, results revealed $\mathrm{LD}_{50}$ of $38 G y$ and $0.08 \%$, respectively, for BNARI-UK accession, and $37 G y$ and $0.27 \%$ for Bankye Borodie (BB) accession (Fig. 1). In previous studies, $\mathrm{LD}_{50}$ for gamma rays and EMS concentration for sprouting of cassava
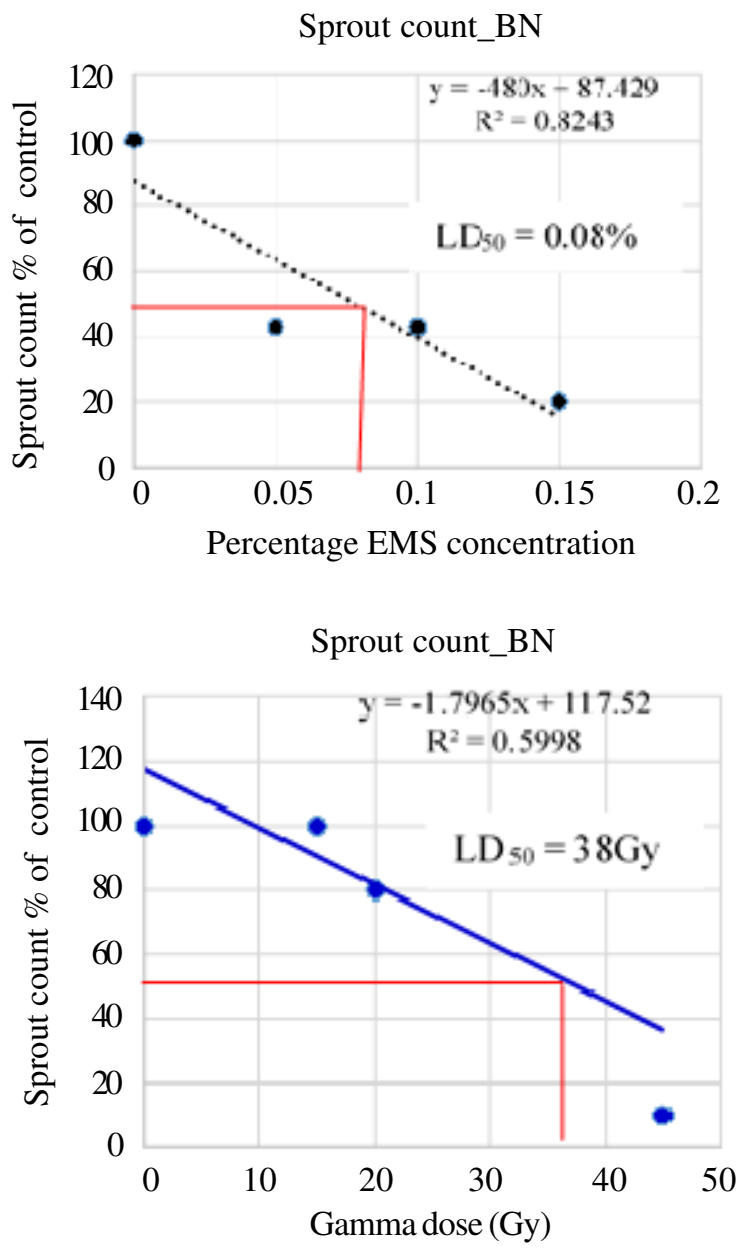

Figure 1. $\mathrm{LD}_{50}$ for sprout of cassava stakes of EMS-treated and $\gamma$-irradiated stakes in one BNARI (BN) accession. 
cuttings was $27.5 G y$ and $1.5 \%(\sim 122 \mathrm{Mm})$ respectively (Kangarasu et al., 2014); and 32Gy (Amenorpe, 2004). Thus, these results suggest that higher irradiation doses and EMS concentrations than the optimal ones are inhibitory to sprouting of cassava stakes. Beyond the optimal doses/concentrations, irreparable chromosomal or entire genome damage and tissue death occurs. Also, at high gamma doses, growth is inhibited due to cell cycle arrest at growth phase 2 (G2) during mitotic division in somatic cells (Minisi et al., 2013). Determination of $\mathrm{LD}_{50}$ is important because it helps to prevent excessive loss of actual experimental materials. At the gamma doses and EMS concentrations used in this study, it was not possible to determine lethal dose $\left(\mathrm{LD}_{50}\right)$ for seed germination. This is because the gamma doses and EMS concentrations used in this study were suboptimal with less or no poisoning potential to the seeds. Thus, further studies are needed for this purpose.

Impact of mutagenesis on morphometric traits. There was a general decrease in sprout, petiole length and number of leaf lobes with increasing doses of gamma rays (Table 1a) and EMS concentration (Table 1b). On the contrary, there was an increase in total chlorophyll content with increasing doses of gamma irradiation; while for EMS treatments, the increase peaked at $0.1 \%$ and then decreased with further increase in concentration. Meanwhile, shoot height increased with gamma dose and decreased with increase in EMS concentration. Hamideldin and Hussin (2014) also reported similar effects of gamma irradiation on potato and attributed the cause to changes in DNA patterns within the potato varieties that were used. The impact of gamma irradiation was more obvious than that of EMS treatment (Fig. 2 ), and more peculiar morphometric characters were noticed in plantlets derived from gamma irradiated stakes (Fig. 3) with most of the characters observed at $20 G y$ treatment. Thus, characters at this gamma irradiation dose may be valuable in early assessment of effectiveness of irradiation to induce mutations and stimulation of traits of agronomic importance, including disease and pest resistance in the crop.

It is plausible that the more pronounced effects of gamma irradiation than EMS treatment is because the latter only causes point mutations, whereas the former causes chromosomal breakages and rearrangements or deletions (Bhat et al., 2007); hence resulting in greater biological effect with easily recognisable phenotypic traits. Also, the failure of stakes to sprout at $45 G y$ may have been due to the highly toxic gamma irradiation levels that led to metabolic activity breakdown. Gamma rays are known to interact with atoms or molecules (e.g. water, proteins, lipids, ascorbic acid, carotenoids and enzymes such as proteases and peroxidase) (Hameed et al., 2008) to produce free radicals in cells such as hydrogen and hydroxide ions, quinones and celluloses (Calucci et al., 2003, which can damage important components of plant cells; hence affecting their morphology, anatomy, biochemistry and physiological characters (Ashraf et al., 2003). For example, peroxidase enzyme activity was found to be higher in seedlings derived from irradiated chickpea seeds, which consequently inhibited their growth (Hameed et al., 2008). Ultimately, the radicals cause inhibitory changes in plant structure and metabolism including growth (Kim et al., 2004; Wi et al., 2005).

Similarly, the effects of gamma irradiation and EMS treatment were observed on seed germination, epicotyl length, shoot heights and chlorophyll content (Table 2). The results showed no significant differences $(\mathrm{P}>0.05)$ in germination, shoot height and chlorophyll content in plants derived from both gammairradiated (Table 2a) and EMS-treated seeds (Table 2b), except for epicotyl length which varied significantly in irradiated seeds $(\mathrm{P}=0.002)$ and not significantly in EMS-treated seeds $(\mathrm{P}=0.08)$ (Table 2b). Relatedly, an 
TABLE 1a. Cassava plant growth characteristics and chlorophyll content of putative mutants derived from gamma irradiated cassava stakes

\begin{tabular}{|c|c|c|c|c|c|c|c|c|c|c|}
\hline \multirow[t]{2}{*}{ Gamma dose $(G y)$} & \multicolumn{2}{|c|}{ Sprout (\% of control) } & \multicolumn{2}{|c|}{$\begin{array}{l}\text { Shoot height } \\
(\% \text { of control) }\end{array}$} & \multicolumn{2}{|c|}{$\begin{array}{l}\text { Petiole length } \\
(\% \text { of control) }\end{array}$} & \multicolumn{2}{|c|}{$\begin{array}{l}\text { Number of leaf } \\
\text { lobes }(\% \text { of control) }\end{array}$} & \multicolumn{2}{|c|}{$\begin{array}{l}\text { Chlorophyll content } \\
\text { (\% of control) }\end{array}$} \\
\hline & BB & $\mathrm{BN}$ & BB & $\mathrm{BN}$ & BB & $\mathrm{BN}$ & BB & $\mathrm{BN}$ & BB & $\mathrm{BN}$ \\
\hline 0 (Control) & 100 & 100 & 100 & 100 & 100 & 100 & 100 & 100 & 100 & 100 \\
\hline 15 & 100 & 100 & 129 & 101 & 105 & 97 & 100 & 86 & 105 & 110 \\
\hline 20 & 100 & 71 & 121 & 128 & 88 & 93 & 86 & 71 & 121 & 116 \\
\hline 30 & 100 & 86 & 99 & 115 & 64 & 74 & 71 & 71 & 120 & 119 \\
\hline 45 & 0 & 14 & 0 & 0 & 0 & 0 & 0 & 0 & 0 & 0 \\
\hline Mean* & 80 & 74 & 90 & 89 & 71 & 73 & 71 & 66 & 89 & 89 \\
\hline LSD & 8.8 & 8.8 & 1.6 & 1.6 & 0.4 & 0.4 & 0.2 & 0.2 & 0.7 & 0.7 \\
\hline \multicolumn{11}{|c|}{$\begin{array}{l}\text { *Means for sprout }(\mathrm{P}=0.006) \text { and shoot height }(\mathrm{P}<0.001) \text { were significantly different while for petiole length }(\mathrm{P}=0.3) \text {, leaf lobes }(\mathrm{P}=0.2) \text { and chlorophyll content }(\mathrm{P}=0.5 \\
\text { were not significantly different at } 5 \% \text {. } \mathrm{BB}=\mathrm{B} \text { ankye Burodie and } \mathrm{BN}=\mathrm{BNARI-UK} \text { accession }\end{array}$} \\
\hline \multirow[t]{2}{*}{ EMS concentration (\%) } & \multicolumn{2}{|c|}{ Sprout (\% of control) } & \multicolumn{2}{|c|}{$\begin{array}{l}\text { Shoot height } \\
(\% \text { of control) }\end{array}$} & \multicolumn{2}{|c|}{$\begin{array}{l}\text { Petiole length } \\
(\% \text { of control) }\end{array}$} & \multicolumn{2}{|c|}{$\begin{array}{l}\text { Number of leaf } \\
\text { lobes }(\% \text { of control) }\end{array}$} & \multicolumn{2}{|c|}{$\begin{array}{l}\text { Chlorophyll content } \\
\text { (\% of control) }\end{array}$} \\
\hline & BB & $\mathrm{BN}$ & BB & $\mathrm{BN}$ & BB & $\mathrm{BN}$ & BB & $\mathrm{BN}$ & BB & $\mathrm{BN}$ \\
\hline 0 (Control) & 100 & 100 & 100 & 100 & 100 & 100 & 100 & 100 & 100 & 100 \\
\hline 0.05 & 67 & 33 & 79 & 118 & 106 & 118 & 86 & 86 & 98 & 73 \\
\hline 0.1 & 83 & 33 & 87 & 82 & 95 & 86 & 100 & 71 & 103 & 113 \\
\hline 0.15 & 67 & 33 & 64 & 61 & 88 & 104 & 86 & 71 & 90 & 98 \\
\hline Mean* & 79 & 50 & 83 & 90 & 97 & 102 & 93 & 82 & 98 & 96 \\
\hline $\operatorname{LSD}(0.05)$ & 16.3 & 16.3 & 2.0 & 2.0 & 0.8 & 0.8 & 0.3 & 0.3 & 0.8 & 0.8 \\
\hline
\end{tabular}

*Means for sprout $(\mathrm{P}=0.9)$, petiole length $(\mathrm{P}=0.2)$ and leaf lobes $(\mathrm{P}=0.09)$ were not significantly different whereas means for shoot height $(\mathrm{P}=0.04)$ and chlorophyll content $(\mathrm{P}<0.001)$ was significantly different at $5 \%$ at different EMS concentrations. Petiole length stimulated at $0.05 \%$ EMS concentration, while chlorophyll content was stimulated at $0.1 \%$ EMS concentration 


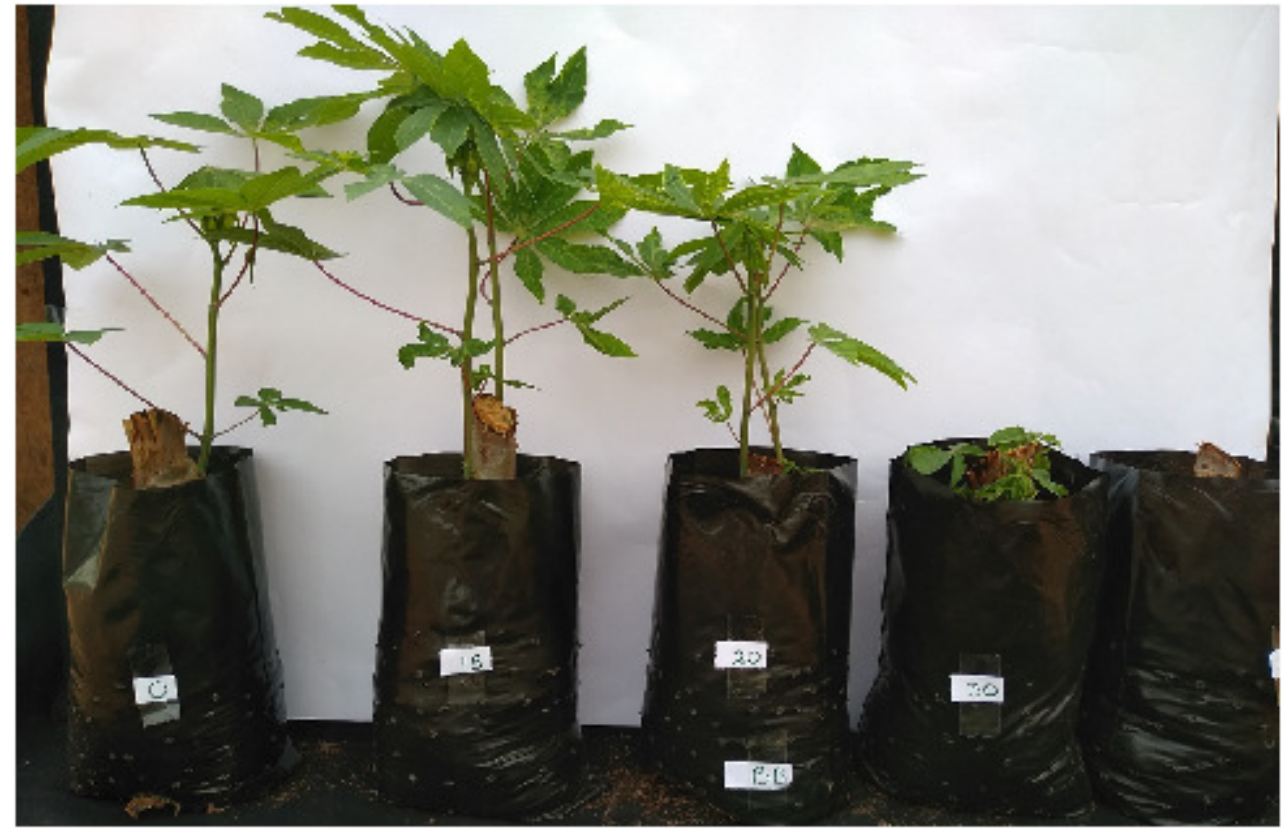

Figure 2. Effect of gamma irradiation on growth of cassava stakes of variety Bankye burodie (BB) at 21 days after planting. The plantlets represent effects of irradiation at $0,15,20,30$ and $45 G y$, respectively.
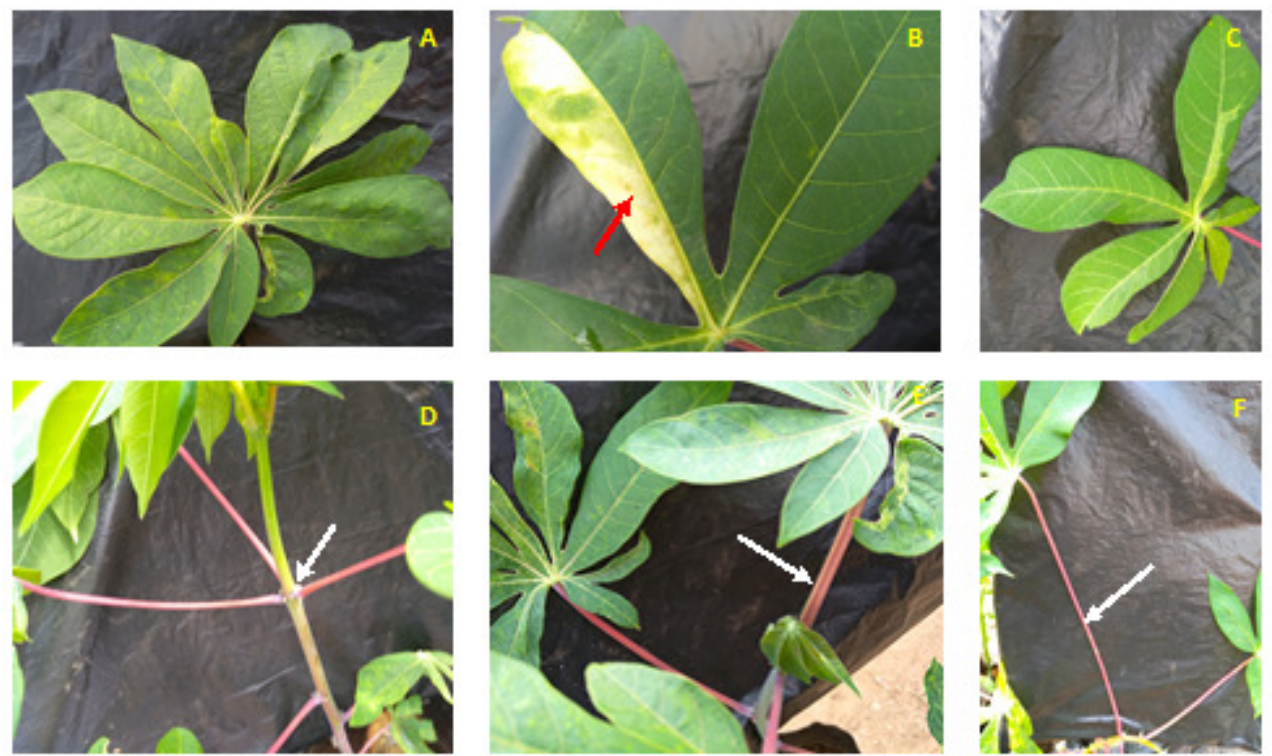

Figure 3. Peculiar characters noticed on cassava plantlets derived from gamma-irradiated stakes. The arrows show the peculiar characteristics exhibited in the plantlets. (A) Increased number of leaf lobes_20Gy, (B) Chlorophyll chimerism_15Gy, (C) Irregular leaf lobes_30Gy, (D) Whorled leaf arrangement_30Gy, (E) Thickened petiole_20Gy, (F) Elongated petiole_20Gy. 
TABLE 2a. Cassava plant growth characteristics and chlorophyll content of putative mutant plants derived from irradiated seeds of NASE 14

\begin{tabular}{lcccc}
\hline Gamma dose $(G y)$ & $\begin{array}{r}\text { Germination } \\
(\% \text { of control })\end{array}$ & $\begin{array}{c}\text { Epicotyl height } \\
(\% \text { of control })\end{array}$ & $\begin{array}{l}\text { Shoot height } \\
(\% \text { of control })\end{array}$ & $\begin{array}{l}\text { Chlorophyll content } \\
(\% \text { of control })\end{array}$ \\
\hline 0 & 100 & 100 & 100 & 100 \\
100 & 87 & 57 & 65 & 152 \\
200 & 175 & 102 & 102 & 116 \\
300 & 50 & 48 & 96 & 112 \\
400 & 125 & 86 & 107 & 99 \\
& & & & 116 \\
Mean & 108 & 79 & 94 & 3.2 \\
LSD $(0.05)$ & 25.1 & 1.1 & 6.5 & \\
\hline
\end{tabular}

TABLE 2b. Cassava plant growth characteristics and shoot height and chlorophyll content of cassava mutant plants from EMS treated seeds of NASE 14

\begin{tabular}{lcccc}
\hline EMS concentration $(\%)$ & $\begin{array}{c}\text { Germination } \\
(\% \text { of control })\end{array}$ & $\begin{array}{c}\text { Epicotyl height } \\
(\% \text { of control })\end{array}$ & $\begin{array}{c}\text { Shoot height } \\
(\% \text { of control })\end{array}$ & $\begin{array}{c}\text { Chlorophyll content } \\
(\% \text { of control })\end{array}$ \\
\hline 0 & 100 & 100 & 100 & 100 \\
0.05 & 123 & 88 & 117 & 103 \\
0.1 & 131 & 102 & 123 & 108 \\
0.15 & 108 & 93 & 113 & 109 \\
Mean & 115 & 96 & 113 & 105 \\
LSD $(0.05)$ & 25.8 & 1.2 & 3.6 & 2.9 \\
\hline
\end{tabular}

inverse relationship between germination of gamma-irradiated chickpea seeds and irradiation doses was reported (Hameed et al., 2008). This inhibitory effect of irradiation is likely to have been caused by the stress effect of free radicals formed upon irradiation of seeds (Rogozhin et al., 2000).

On the contrary, seed germination decreased with increasing concentration of EMS in Basmati rice (Wattoo et al., 2013).This was attributed to the lethality of EMS which may have caused a drop in auxin levels, chromosomal abrasions or due to decline in the uptake of assimilates. The EMS concentrations used in this study may not have been lethal enough to adversely affect the biochemistry or physiology of the germinating seeds.
Contrastingly, chlorophyll content increased at all gamma doses, except 400Gy (Table 2a) and EMS concentrations (Table 2b) compared to control. Singh (1971) and Idrees et al. (2007) obtained results with a similar trend on application of gamma irradiation. The increased chlorophyll content was due to a stimulatory effect on the development of meristematic cells that led to the synthesis and accumulation of auxin, which is believed to have an important role in chlorophyll accumulation. Meanwhile, results of increase in chlorophyll content with EMS concentration are in agreement with those reported by Junaid et al., (2008), though the content decreased with further increase in EMS concentration. The increased chlorophyll content could have been due to a mutant type induced by EMS. 
Therefore, the EMS concentrations used in this study were below the lethal limits and hence were beneficial in stimulating chlorophyll production.

The trends for epicotyl length and shoot heights were not consistent. However, for gamma irradiation, most stimulation was at $200 G y$, while for EMS treatment this was at $0.1 \%$. Decreased shoot length with increasing gamma dose in chickpea (Hameed et al., 2008) and EMS concentration in Dracaena sanderiana (Junaid et al., 2008) and Coriandrum sativum L. (Kumar and Pandey, 2019) were previously reported. The growth stimulatory effect of low gamma doses was ascribed to a change in the hormonal signaling network in plant cells or an increasing antioxidative capacity of the cells so as to easily overcome stresses (Minisi et al., 2013). Meanwhile, the stimulatory effect at lower EMS concentrations, congruent with the observations in this study, can be attributed to a stimulated cell division that caused the epicotyls to elongate.

Meristem culture initiation. Though analyses revealed no significant differences in response of meristem tips derived from irradiated and EMS-treated stakes $(\mathrm{P}=0.9$ and $\mathrm{P}=0.8$, respectively), meristem response decreased with increase in gamma dose and EMS concentration, except for one variety, BNARI-UK (BN), in which the response increased with EMS concentration (Fig. 4). Contrary to the results of the gamma-treated meristems in this study, Shin et al. (2011) reported easy regeneration of axillary buds into shoots on stems of gamma-irradiated sweet potato. The reduction in regeneration response in this study can be attributed to chromosomal damage in the cells by the high gamma doses, while the lower doses may have been stimulatory for high meristem responses. However, the results of the EMS treatment in this study are in accordance with Sadat and Hoveize (2012) who also observed failure of plant regeneration from sugarcane plantlets exposed to increasing concentrations of EMS. This was attributed to the poisonous effect of EMS on plant cells as the concentration increased. On the other hand, the increased meristem response of BINARI-UK with increase in EMS concentration may have been due to a stimulatory effect based on varietal/ genotypic differences. This, therefore means that EMS solutions may be efficiently used to speed up induction and regeneration of new plants (with mutations of agronomic importance) in cassava breeding programmes.

\section{Whitefly infestation, CMD incidence and} severity. Generally, the results revealed increased whitefly infestations and CMD severity in both cassava accessions, all of which were maximum at gamma dose $30 G y$ (Table 3a). However, the lowest whitefly infestation and CMD severity were recorded at $20 G y$ and $15 G y$, respectively for accession $\mathrm{BB}$, which could, therefore, be considered as tolerant.

Although literature on mutagenic induction of resistance to pests in plants is scanty, it can be postulated that the $20 G y$ gamma dosage caused changes in the DNA that resulted in antibiotic compounds such as phenolics and proteinase inhibitors that may have imparted some resistance to whitefly infestation (Jan et al., 2012). At 30Gy, the DNA was damaged leading to so severe stresses that broke down the defence mechanism to render the plants susceptible to infestation (Ouhibi et al., 2015).

The lower incidence and increased resistance to diseases induced by irradiation at lower gamma irradiation have been reported in pear fruits (Pyrus pyrifolia "Niitaka") (Jeong et al., 2017) and mutants of Citrus reticulata and Oryza sativa (Raina and Danish, 2018). Studies have further reported that lower gamma doses are more effective at inducing disease resistance than higher ones because the latter causes DNA damage, resulting in secondary adduct molecules involved in induction of defence mechanisms against diseases in plant tissues (Ouhibi et al., 2015). 

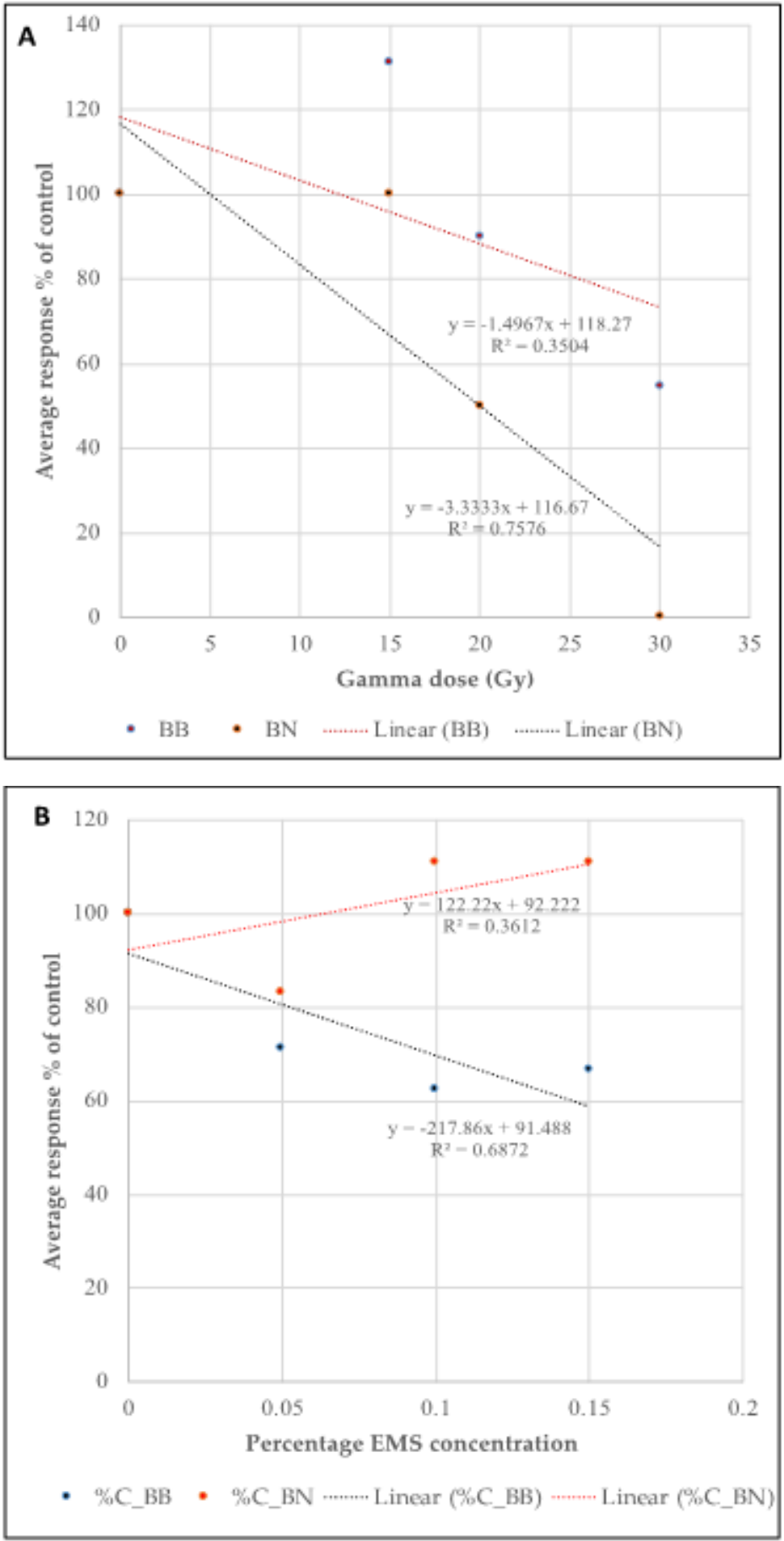

Figure 4. Cassava meristem culture response: (A) response decreased with increase in gamma dose; (B) response for BB decreased as that for BN increased with increase in EMS concentration. 
TABLE 3a. Whitefly count, CMD incidence and severity in putative mutant plants derived from irradiated cassava stakes

\begin{tabular}{|c|c|c|c|c|c|c|}
\hline \multirow[t]{2}{*}{ Gamma dose $(G y)$} & \multicolumn{2}{|c|}{ Whitefly count } & \multicolumn{2}{|c|}{ CMD incidence } & \multicolumn{2}{|c|}{ CMD severity } \\
\hline & $\mathrm{BB}$ & $\mathrm{BN}$ & $\mathrm{BB}$ & $\mathrm{BN}$ & $\mathrm{BB}$ & $\mathrm{BN}$ \\
\hline 0 (Control) & 5.6 & 5.1 & 0.9 & 0.9 & 1.4 & 1.8 \\
\hline 15 & 5.3 & 5.4 & 0.6 & 0.4 & 1.1 & 1.8 \\
\hline 20 & 3.8 & 7.4 & 1.0 & 0.7 & 1.2 & 2.3 \\
\hline 30 & 8.5 & 8.0 & 0.6 & 1.0 & 2.4 & 2.3 \\
\hline 45 & - & - & - & - & - & - \\
\hline Mean* & 5.7 & 5.9 & 0.8 & 0.7 & 1.5 & 2.0 \\
\hline $\operatorname{LSD}(0.05)$ & 1.0 & 1.0 & 0.1 & 0.1 & 0.2 & 0.2 \\
\hline
\end{tabular}

* Means for whitefly count $(\mathrm{P}=0.04), \mathrm{CMD}$ incidence $(\mathrm{P}=0.006)$ and $\mathrm{CMD}$ severity $(\mathrm{P}=0.004)$ were all significantly different at $5 \%$.

TABLE 3b. Whitefly count, CMD incidence and severity in putative mutant plants derived from EMS treated cassava stakes

\begin{tabular}{|c|c|c|c|c|c|c|}
\hline \multirow[t]{2}{*}{ EMS concentration $(\%)$} & \multicolumn{2}{|c|}{ Whitefly count } & \multicolumn{2}{|c|}{ CMD incidence } & \multicolumn{2}{|c|}{ CMD severity } \\
\hline & $\mathrm{BB}$ & $\mathrm{BN}$ & $\mathrm{BB}$ & $\mathrm{BN}$ & $\mathrm{BB}$ & $\mathrm{BN}$ \\
\hline 0 (Control) & 4.0 & 10.3 & 1.0 & 1.0 & 1.7 & 2.3 \\
\hline 0.05 & 5.9 & 5.7 & 1.0 & 0.5 & 1.8 & 3.0 \\
\hline 0.1 & 7.7 & 5.3 & 0.9 & 1.0 & 1.8 & 2.0 \\
\hline 0.15 & 6.0 & 9.6 & 0.9 & 1.0 & 1.6 & 2.0 \\
\hline Mean & 5.8 & 8.6 & 1.0 & 0.9 & 1.8 & 2.3 \\
\hline $\operatorname{LSD}(0.05)$ & 1.7 & 1.7 & 0.1 & 0.1 & 0.3 & 0.3 \\
\hline
\end{tabular}

Means for whitefly count $(\mathrm{P}=0.005)$ and $\mathrm{CMD}$ incidence $(\mathrm{P}<0.001)$ were significantly different while that for $C M D$ severity $(\mathrm{P}=0.09)$ was not significantly different at $5 \%$.

In the present study, irradiation at $30 G y$ seems to have been beyond optimal and caused severe damage to the DNA that resulted in severe stress in the plants, thus boosting their susceptibility to CMD infection.

On the other hand, whitefly infestation and CMD incidence varied significantly with EMS concentration and among accessions (Table 3b). Whitefly infestation was generally higher in the treatments than in the control and peaked at $0.1 \%$ EMS concentration in accession BB. This can be regarded as susceptible, while in accession $\mathrm{BN}$ the infestation was lower than control, peaking at $0.15 \%$ concentration. This can be inferred as tolerant. All accessions exhibited foliar symptoms of CMD at all EMS concentrations; however, reduced or tolerance levels (lowest incidence and severity) were noted at $0.05 \%$ and $0.1-0.15 \%$ in accession $\mathrm{BN}$. 
The low whitefly infestation and CMD infection levels could be a sign of acquired tolerance (Simons, 1971). This can be attributed to EMS treatment, which could have induced cell wall fortification or release of chemicals such as phytoalexins and antioxidants, or enhancement of the activity of disease resistance- related enzymes (Simons, 1971; Daayf et al., 2012); these may have aided in the reduction in whitefly and CMD prevalence. The different tolerances or susceptibilities to whitefly infestations and CMD infection, following gamma irradiation and EMS treatment study can be explained by the differences in resistance genes and/or genetic constitutions of the different cassava accessions (BB and $\mathrm{BN}$ ) that were used.

It is worth to note that various mutant crops with improved and stable resistance to a number of diseases induced mainly by gamma irradiation have been reported (Maluszynski $e t$ al., 2000; Ahloowalia et al., 2004; Pathirana, 2014). In this regard, over 320 cultivars resistant to different diseases have been obtained either as direct mutants or derived from hybridisation with mutants, or through self- or cross-fertilisation (Kozjak and Megliè, 2016). For example, using gamma irradiation, disease resistance has been induced in crops such as rice against rice blast and rice yellow mottle virus; mungbean against yellow mosaic virus; soybean against myrothecium leaf spot, yellow mosaic virus and rust; and cotton against bacterial blight and cotton leaf curl virus (Pathirana, 2014). Similarly, chemical mutagenesis has been used to create resistance to pathogen and disease outbreak in crops such as cabbage, Brassica oleracea (Maluszynski et al., 2000) and soybean, Glycine max (Khan and Tyagi, 2013). Thus, the results obtained in this study give a great possibility for inducing durable resistance to common cassava viral diseases and pests as well as morphometric variability that may be of significance in cassava breeding.

\section{CONCLUSION}

The $\mathrm{LD}_{50}$ doses based on the sprouting of stakes after treatment with different doses of gamma rays and different concentration of EMS were $38 G y$ and $0.08 \%$, and $37 G y$ and $0.27 \%$ for cassava accessions BNARI-UK (BN) and Bankye Borodie (BB), respectively. The $\mathrm{LD}_{50}$ mutagen doses determined for cassava accessions in this study will be useful in guiding determination of gamma dosage and EMS concentration to use in future cassava mutation breeding programmes. Gamma irradiation influenced morphometric traits more than EMS treatment and accession BB was generally more sensitive and responsive to both treatments than BN.

The different morphometric traits observed may be helpful in early assessment of effectiveness and potentiality of the mutagenic agent in a breeding programme. Although some of the resulting morphometric traits may be undesirable, they can be a source of enormous variation for practical utility in the generation of new crop varieties. This study demonstrates that gamma rays and EMS may be valuable mutagens in inducing resistance and/or tolerance to whitefly infestation and CMD infection, though exposure to low doses of gamma (15-20Gy) is a more promising approach than EMS treatment when using cassava stakes. Further investigation of effects of mutagenesis on viral disease and whitefly resistance as well as economically important agronomic traits under field conditions could yield cassava varieties with desired resistance, while identification of compounds, molecular markers and QTL associated with the induced resistance could provide deeper knowledge.

\section{ACKNOWLEDGEMENT}

This study was conducted while undertaking a mutation breeding fellowship training at BNARI, Ghana with support from 
the International Atomic Energy Agency (IAEA) through a Technical Cooperation Project (Grant number UGA5041). Funding for this publication was received from the IAEA Coordinated Research Project No. D24014, through Research Contract No. 24486. We thank staff at Radiation Technology Centre for gamma irradiation services, Mr. James Opoku Frimpong and Daniel Eyram Cofie, National Service staff at BNARI for helping in data collection, Dr. Godfrey Asea, Director of Research, NaCRRI and the team at the Nuclear Energy Unit, Ministry of Energy and Mineral Development, Government of Uganda for their support.

\section{REFERENCES}

Adenle, A.A., Aworh, O.C., Akromah, R. and Parayil, G. 2012. Developing GM super cassava for improved health and food security: Future challenges in Africa. Agriculture and Food Security 1(11):1-15. doi: 10.1186/2048-7010-1-11.

Amenorpe, G., Amoatey, H.M. and Asare, D. 2004. Breeding for drought tolerance/ avoidance and mealyness in cassava using gamma radiation. GAEC/BNARI Annual Report. pp. 22-23.

Ashraf, M., Cheema, A.A., Rashid, M. and Qamar, Z. 2003. Effect of $\gamma$-rays on M1 generation in basmati rice.Pakistan Journal of Botany 35.791-795.

Bhat, R., Upadhyaya, N., Chaudhury, A., Raghavan, C., Qiu, F., Wang, H., Wu, J., McNally, K., Leung, H. and Till, B. 2007. Chemical and irradiation induced mutants and TILLING. Rice Functional Genomics. pp. 148-180. https://doi.org/10.1007/0-38 7-48914-2_8

Calucci, L., Pinzino, C., Zandomeneghi, M., Capocchi, A., Ghiringhelli, S., Saviozzi, F., Tozzi, S. and Galleschi, L. 2003. Effect of $\gamma$-irradiation on the free radical and antioxidant contents in nine aromatic herbs and spices. Journal of Agricultural and
Food Chemistry 51(4):927-934. https:// doi.org/10.1021/jf020739n.

Daayf, F., El Hadrami, A., El-Bebany, A. F., Henriquez, M.A., Yao, Z., Derksen, H., ElHadrami, I. and Adam, L.R. 2012. Phenolic compounds in plant defense and pathogen counter-defense mechanisms. Recent Advances in Polyphenol Research 3, 3:191-208. https://doi.org/10.1002/978111 8299753.ch8.

FAO and IAEA. 2011. IAEA mutant database. International Atomic Energy Agency, Vienna, Austria. https://mvd.iaea.org

FAO. 2010. Food and Agricultural Organization of the United Nations. 2010. State of Food Insecurity in World. FAO, Rome, Italy.

FAO. 2011. Food and Agriculture Organization. 2011. Reviving cassava production in Northern Uganda. FAO, Kampala, Uganda. Hameed, A., Shah, T.M., Atta, B.M., Haq, M.A. and Sayed, H. 2008. Gamma irradiation effects on seed germination and growth, protein content, peroxidase and protease activity, lipid peroxidation in desi and kabuli chickpea. Pakistan Journal of Botany 40(3):1033-1041.

Hamideldin, N. and Hussin, O.S. 2014. Morphological, physiological and molecular changes in Solanum tuberosum L. in response to pre-sowing tuber irradiation by gamma rays. American Journal of Food and Nutrition 2(1):1-6. doi: 10.12691/ajfn2-1-1.

Hillocks, R.J. and Thresh, J.M. 1998. Cassava mosaic and cassava brown streak virus diseases in Africa: A comparative guide to Symptoms and Aetiologies. Natural Resources Institute (NRI), Chatham, UK. Idrees, M., Shabab, D. and Khan, M.A. 2007. Effect of gamma irradiation on the chlorophyll content of brinjal. Indian Journal of Applied and Pure Biology 22(2):317-318.

Jan, S., Parween, T., Siddiqi, T.O. and Mahmooduzzafar. 2012. Enhancement in furanocoumarin content and phenylalanine 
ammonia lyase activity in developing seedlings of Psoralea corylifolia L. in response to gamma irradiation of seeds. Radiation and Environmental Biophysics 51(3):341-347. https://doi.org/10.1007/ s00411-012-0421-1.

Jennings, D.L. and Iglesias, C. 2002. Breeding for crop improvement. In: Hillocks, R.J., Thresh, J.M. and Bellotti, A.C. (Eds.), Cassava: Biology, Production and Utilization. CAB International pp. 149-166. Jeong, R.D., Jeong, M.A. and Park, M.R. 2017. Gamma irradiation-induced disease resistance of pear (Pyrus pyrifolia "Niitaka") against Penicillium expansum. Journal of Phytopathology 165(9):626633. https://doi.org/10.1111/jph.12601.

Junaid, A., Mujib, A. and Sharma, M.P. 2008. Effect of growth regulators and ethylmethane sulphonate on growth, andchlorophyll, sugar and proline contents in Dracaena sanderiana cultured in vitro. Biologia Plantarum 52 (3): 569-572. doi: 10.1007/s10535-008-0113-5.

Kangarasu, S., Ganeshram, S. and Joel, A. J. 2014. Determination of lethal dose for gamma rays and ethyl methane sulphonate induced mutagenesis in cassava (Manihot esculenta Crantz). International Journal of Scientific Research 3(1):1-6.

Kawuki, R., Pariyo, A., Nuwamanya, E., Ssemakula, G., Tumwesigye, S., Bua, A., Baguma, Y., Omongo, C., Alicai, T. and Orone, J. 2011. A breeding scheme for local adoption of cassava (Manihot esculenta Crantz). Journal of Plant Breeding and Crop Science 3(7):120-130.

Khan, M.H. and Tyagi, S.D. 2013. A review on induced mutagenesis in soybean. Journal of Cereals and Oilseeds 4(2):1925. https://doi.org/10.5897/jco10.004.

Khumaida, N., Ardie, S.W. and Astuti, M.S. 2017. Characterization of irradiation induced mutants of cassava (Manihot esculenta Crantz) generated from Jamejame and Adira-4 genotypes at M1V2 generation. In: $2^{\text {nd }}$ International Conference on Sustainable Agriculture and Food Security: A Comprehensive Approach. Knowledge E Life Sciences. pp. 22-28. doi: 10.18502/kls.v2i6.1016.

Khumaida, N., Ardie, S.W., Dianasari, M. and Syukur, M. 2015. Cassava (Manihot esculentaCrantz.) improvement through gamma irradiation. Procedia Food Science 3:27-34. doi: 10.1016/j.profoo.2015.01. 003.

Kim, J.H., Baek, M.H., Chung, B.Y., Wi, S.G. and Kim, J.S. 2004. Alterations in the photosynthetic pigments and antioxidant machineries of red pepper (Capsicum annuum L.) seedlings from gammairradiated seeds, Journal of Plant Biology 47:314-321.

Kozjak, P. and Megliè, V. 2016. Mutagenesis in plant breeding for disease and pest resistance. In: Mutagenesis. pp. 196-220. doi: http://dx.doi.org/10.5772/57353.

Kumar, G. and Pandey, A. 2019. Ethyl methane sulphonate induced changes in cytomorphological andbiochemical aspects of Coriandrum sativum L. Journal of the Saudi Society of Agricultural Sciences 18: 469-475.

Legg, J.P., Jeremiah, S.C., Obiero, H.M., Maruthi, M.N., Ndyetabula, I., OkaoOkuja, G., Bouwmeester, H., Bigirimana, S., Tata-Hangy, W., Gashaka, G., Mkamilo, G., Alicai, T. and Lava Kumar, P. 2011. Comparing the regional epidemiology of the cassava mosaic and cassava brown streak virus pandemics in Africa. Virus Research 159(2):161-170. https://doi.org/10.1016/ j.virusres.2011.04.018.

Lister, R.M. 1959. Mechanical transmission of cassava brown streak virus. Nature 183:1588-1589.S. doi: 10. 1038/183158 $8 \mathrm{~b} 0$.

Liu, L., Van Zanten,L., Shu, Q. and Maluszynski, M. 2004. Officially released mutant varieties in China. Mutation Breeding Review 14:1-62.

Maluszynski, M., Nichterlein, K., Zanten, V.L., and Ahloowalia, S. 2000. Officially released 
mutant varieties - the FAO/IAEA database pp. 1-88.

Maruthi, M.N., Hillocks, R.J., Mtunda, K., Raya, M.D., Muhanna, M., Kiozia, H., Rekha, A. R., Colvin, J. and Thresh, J.M. 2005. Transmission of Cassava brown streak virus by Bemisia tabaci (Gennadius). Journal of Phytopathology 153(5):307-312. https://doi.org/10.1111/ j.1439-0434.2005.00974.x

Minisi, F., Mohammed, E.E., Magd, E.D.F.R., and Mary, N.N. 2013. Effects of gamma radiation on germination, growth characteristics and morphological variations of Moluccella laevis L. American-Eurasian Journal of Agricultural \& Environmental Sciences 13(5):696-704. https://doi.org/ 10.5829/idosi.aejaes.2013.13.05.1956.

Nassar, N. and Ortiz, R. 2010. Breeding cassava to feed the poor. Scientific American 302(5):78-84. doi: 10.1038/ scientificamerican0510-78.

Njock, T.E. 1994. Epidemiology and disease recovery phenomenon of African cassava mosaic virus in resistant and susceptible cassava clones. Ph.D. thesis. University of Ibadan, Ibadan, Nigeria. 213pp.

Ogwok, E., Alicai, T., Rey, M.E.C., Beyene, G. and Taylor, N.J. 2015. Distribution and accumulation of cassava brown streak viruses within infected cassava (Manihot esculenta) plants. Plant Pathology. pp. 112. doi: 10.1111/ppa.12343.

Ouhibi, C., Attia, H., Nicot, P., Urban, L., Lachaal, M.and Aarrouf, J. 2015. Effect of $\mathrm{UV}$ - C radiation on resistance of romaine lettuce (Lactuca sativa L.) against Botrytis cinerea and Sclerotinia minor. Journal of Phytopathology 163:578-582.

Pathirana, R. 2014. Plant mutation breeding in agriculture. CAB Reviews 2011. Perspectives in Agriculture, Veteriinary Science, Nutrition and Natural Resources 6(032):1-21. https://doi.org/10.1079/ PAVSNNR20116032.

Raina, A. and Danish, M. 2018. Mutagenesis in plant breeding for disease and pathogen resistance. Agricultural Research \& Technology: Open Access Journal 13(1):12-13. doi: 10.19080/artoaj.2018.13. 555869.

Rife, T.W. and Poland, J.A. 2014. Field book: An open source application for field data collection on android. Crop Science 54(4):1624-1627. https://doi.org/10.2135/ cropsci2013.08.0579.

Rogozhin, V.V., Kuriliuk, T.T. and Filippova N.P. 2000. Change in the reaction of the antioxidant system of wheat sprouts after UV-irradiation of seeds. Biofizika 45:730736. PMID: 11040985.

Sadat, S. and Hoveize, M. 2012. Mutation induction using ethyl methanesulfonate (EMS) in regenerated plantlets of two varieties of sugarcane CP48-103 and CP57-614. African Journal of Agricultural Research 7(8):1282-1288. https://doi.org/ 10.5897/AJAR11.1345.

Shimelis, H. and Laing, M. 2012. Timelines in conventional crop improvement: Prebreeding and breeding procedures. Australian Journal of Crop Science 6(11): 1542-1549.

Shin, J.M., Kim, B.K., Seo, S.G., Jeon, S.B., Kim, J.S., Jun, B., Kang, S.Y., Lee, J.S., Chung, M.N. and Kim, S.H. 2011. Mutation breeding of sweet potato by gamma-ray radiation. African Journal of Agricultural Research 6(6):1447-1454. https://doi.org/ 10.5897/AJAR10.936.

Simons, M.D. 1971. Modification of tolerance of oats to crown rust by mutation induced with ethyl methanesulfonate. Phytopathology 61(9):1064-1067. https:// doi.org/10.1094/phyto-61-1064

Singh, B.B. 1971. Effect of gamma irradiation on chlorophyll content of maize leaves. Radiation Botany 11:243-244.

Taylor, N., Chavarraiga. P., Raemakers, C.C.J.M., Siritunga, D. and Zhang, P. 2004. Development and application of transgenic technologies in cassava. Plant Molecular Biology 56:671-688. 
Wattoo, J.I., Aslam, K., Shah, S.M., Shabir, G., Sabar, M., Naveed, S.A. and Arif, M. 2013. Ethyle methane sulphonate (EMS) induced mutagenic attempts to create genetic variability in Basmati rice. African Journal of Water Conservation and Sustainability 1(3):45-48. DOI: 10.5897/ JPBCS11.080.

Wi, S.G., Chung, B.Y., Kim, J.H., Baek, M.H., Yang, D.H., Lee, J.W. and Kim, J.S. 2005
Ultrastructural changes of cell organelles in Arabidopsis stem after gamma irradiation.Journal of Plant Biology 48 (2):195-200.

Yan, H., Lu, L., Hershey, C., Ceballos, H., Chen, S. and Li, K. 2013. Cassava mutation breeding: Current status and trends. In: Nielen, S. (Ed.), Plant Mutation Reports. FAO/IAEA. pp. 37-44. 